Tropical Journal of Pharmaceutical Research, February 2010; 9 (1): 27-34

(C) Pharmacotherapy Group,

Faculty of Pharmacy, University of Benin,

Benin City, 300001 Nigeria.

All rights reserved.

Research Article

Available online at http://www.tjpr.org

\title{
Effect of Growth Regulators and Culture Conditions on Direct Root Induction of Rauwolfia serpentina L. (Apocynaceae) Benth by Leaf Explants
}

\author{
Ved Prakash Pandey*, Elizabeth Cherian and George Patani \\ Dr. Patani Scientific and Industrial Research, PSIR Building, Inga Complex, Mahakali Road, Andheri (E), Mumbai
} 400093, India.

\begin{abstract}
Purpose: Rauwolfia serpentina (L.) Benth, from the family, Apocynaceae, is an important medicinal plant due to the alkaloid content of its root. The purpose of this study was to obtain roots directly from leaf explant using growth regulators.

Methods: The leaf explant was inoculated on MS (Murashige and Skoog) medium supplemented with single and combinations of growth regulators. Root growth was also observed on liquid MS medium and under dark conditions. The reserpine content of the roots obtained was determined by HPLC.

Results: Two combinations of auxins namely, para-amino benzoic acid (PABA) $+\alpha$-naphthalene acetic acid (NAA), and 3-Indole butyric acid (IBA) + NAA, promoted better root growth compared to single auxin treatment. The highest number of roots and regeneration response was observed on leaf explant cultured on MS media supplemented with PABA $\left(1 m g \Gamma^{1}\right)+N A A\left(4 m g \Gamma^{1}\right)$. Liquid MS media gave slower growth, reduced number of roots, shorter root length as well as absence of reserpine, using the same combination of growth regulators, compared to solid MS media. The culture incubated under dark conditions produced thin roots. HPLC analysis of the regenerated roots indicated low alkaloid (reserpine) content $(0.01-0.03)$. However, higher alkaloid content $(0.03 \%)$ was observed in cultures with fewer numbers of roots.

Conclusion: A simple and reliable protocol for direct induction of roots from leaf explant of $R$. serpentina using plant growth regulators has been developed.
\end{abstract}

Keywords: Rauwolfia serpentina; Leaf explant; Root induction; Growth regulators; Auxins; Reserpine. 


\section{INTRODUCTION}

Rauwolfia serpentina (Linn.) Benth. is an important medicinal plant (shrub) belonging to the Apocynaceae family. The plant is indigenous to India and Bangladesh and is found to grow wild in the Asian continent. It has been reported to contain 50 indole alkaloids that are mainly localized in the root bark [1]. Among these alkaloids, reserpine, yohimbine, serpentine, deserpidine, ajmalicine and ajmaline are used to treat hypertension [2] and breast cancer [3]. Reserpine, used as a natural tranquilizer was found to have several times greater hypotensive activity than the crude plant extract [4]. Rauwolfia root is reported to contain $0.7-3.0 \%$ of total alkaloids in the dry mass and the amount varies with time and source of collection [5].

The rate of plant propagation is important for commercial cultivation to meet the pharmaceutical demand for reserpine. Chemical synthesis of reserpine has not been adopted due to its high cost compared to extraction from the natural source [6]. While roots of $R$. serpentina is the main source of the alkaloids mentioned above, indiscriminate harvesting of the roots has threatened the survival of the plant. However, high demand for the alkaloids necessitates rapid production of roots within a short time-frame. Therefore, root cultures are a potentially useful in vitro system for commercial production of secondary metabolites. Direct root induction from leaf explant as a method for the rapid root regeneration has been reported for several plants, viz, Lycopersicon esculentum [7], Nicotiana tabacum [8], and Begonia [9]. Shrivastava and Padhya [10] obtained root induction from the leaf segment of Boerhaavia diffusa on MS medium containing indole-3-acetic acid (IAA). The leaf explant of Ophiorrhiza prostrata showed root formation on kinetin and NAA combination [11]. Tuan et al [12] were able to derive roots from the leaf of Eustoma grandiflorum while direct root growth from the leaf explant of Cydonia oblonga has also been reported by
D'onofrio and Morini [13]. Root induction has also been obtained from the leaf of Helianthus occidentalis using a combination of 6-benzyl aminopurine (BAP) and NAA [14].

Rauwolfia serpentina roots are generally obtained through shoot organogenesis [15], callus morphogenesis [16] or by Agrobacterium rhizogenes-mediated transformation [17-19]. So far, no protocol has been published for in vitro growth of $R$. serpentina roots directly from leaf explant using growth regulators. The present study was undertaken to develop a protocol for rapid induction of $R$. serpentina roots using the leaf of the plant as the starting material.

\section{EXPERIMENTAL}

\section{Plant material}

Leaf explants of Rauwolfia serpentina were collected from the plantation of Dr. Patani Scientific and Industrial Research (PSIR), Andheri (E), Mumbai, India. A voucher specimen (voucher no. RD/RS/08/PN22) was preserved for future reference at the herbarium of PSIR Laboratory, Mumbai, India.

\section{Chemicals and reagents}

Agar and $\alpha$-naphthalene acetic acid (NAA) were purchased from SD Fine Chemical, Mumbai while 3-Indole butyric acid (IBA), indole-3-acetic acid (IAA), 6-benzyl aminopurine (BAP) and Murashige and Skoog (MS) media constituents were obtained from Merck Ltd. Mumbai; paraamino benzoic acid (PABA) was provided by Sisco Research Ltd. Mumbai.

\section{Sterilization of explant}

Explants were placed under running tap water for $20 \mathrm{~min}$ and then washed with a mixture of 1 drop of Tween 80 and 2 drops of Dettol (in $150 \mathrm{ml}$ distilled water) for $10 \mathrm{~min}$ followed by thorough washing with distilled water to remove traces of the germicidal 
agent. They were further surface-sterilized with $0.1 \% \mathrm{w} / \mathrm{v}$ mercuric chloride $\left(\mathrm{HgCl}_{2}\right)$ for 10 min followed by washing them five times with sterile distilled water. Disinfected explants were cut into small pieces $(1.5-2.0$ $\mathrm{cm})$ and aseptically transferred to MS medium [20] at $\mathrm{pH} 5.6$ (adjusted prior to autoclaving at $121^{\circ} \mathrm{C}$ and $1.06 \mathrm{~kg} / \mathrm{cm}^{2}$ for 20 min), supplemented with growth regulators, 3 $\%$ sucrose and $0.6 \%$ agar. The cultures were incubated at $25 \pm 2{ }^{\circ} \mathrm{C}$ with a light intensity of 3000-Lux using white fluorescent lamps. A photoperiod of $16 / 8$ light and dark cycle was maintained.

\section{Concentration and combinations of growth regulators, and culture conditions}

The leaf explant was inoculated on MS medium with single and combinations of growth regulators. For root induction, explants were cultured on MS medium containing different concentrations of auxins, viz, IAA (indole-3-acetic acid), IBA, PABA, and NAA, individually at concentrations ranging from 0.5 to $10 \mathrm{mg} \mathrm{l}^{-1}$. In another experiment, leaf explants were cultured on MS medium containing combination of two auxins, e.g., $\operatorname{PABA}(0.5,1,1.5,2,2.5$ and 3 $\left.\mathrm{mg} \mathrm{I}^{-1}\right)$ and NAA $\left(1,2,3,4\right.$ and $\left.5 \mathrm{mg} \mathrm{l}^{-1}\right)$. Combinations of other auxins, i.e., IBA and NAA; IAA and NAA, were also assessed at the same concentrations as those stated for PABA and NAA. Rooting response of the explants were observed on solid MS medium containing cytokinin, i.e., BAP (6-benzyl aminopurine) and auxin (i.e., NAA) combinations at concentrations ranging from 0.5 to $5 \mathrm{mg} \mathrm{l}^{-1}$. In yet another experiment, leaf segments were cultured on liquid MS medium, with the same concentrations of growth regulators as that used for the solid MS medium. The leaf explant on MS media supplemented with PABA and NAA were also incubated under dark conditions.

\section{Extraction and determination of reserpine}

Six months old in vitro roots were dried and ground to coarse powder. The powder was extracted with $2 \times 50 \mathrm{ml}$ of ethanol (95\%) and quantitatively analysed by HPLC (Shimadzu, Japan, model LC - 10AT) using reserpine (Indo German Alkaloids, Mumbai) as standard; $25 \mathrm{~cm} \times 4.6 \mathrm{~mm}$ ODS Machery - Nagel column, mixture of 35 volumes of acetonitrile and 65 volumes of buffer $(\mathrm{pH} 3)$ (prepared by dissolving $6.8 \mathrm{~g}$ potassium dihydrogen orthophosphate in $1000 \mathrm{ml}$ water, $\mathrm{pH}$ of which is adjusted to 3.0) as the mobile phase; a flow rate of $1 \mathrm{ml} / \mathrm{min}$; and a $268 \mathrm{~nm}$ detector [21].

\section{Statistical analysis}

The data are presented as mean \pm SE of 15 explants per treatment and repeated thrice. Data were statistically analysed using Duncan's multiple range test $(P \leq 0.05)$.

\section{RESULTS}

\section{Influence of MS media on root induction}

Leaf segments inoculated on MS medium devoid of growth regulators but with either IAA, IBA or PABA failed to produce roots and the explants turned brown within four weeks of incubation. However, as Table 1 shows, there was evidence of root induction on MS medium containing $4.5 \mathrm{mg} \mathrm{I}^{-1} \mathrm{NAA}$ after four weeks of inoculation. MS medium supplemented with $8.5 \mathrm{mg} \mathrm{l}^{-1}$ NAA showed callus and root formation with $0.01 \%$ of reserpine. Treatment with $6 \mathrm{mg} \mathrm{I}^{-1} \mathrm{NAA}$ produced 12 roots per explant and $0.02 \%$ reserpine (Table 1). The highest regeneration response and number of roots were recorded for the auxin combinations, PABA + NAA and IBA + NAA, respectively. MS medium containing $1 \mathrm{mg} \mathrm{l}^{-1}$ PABA $+4 \mathrm{mg} \mathrm{l}^{-1}$ NAA showed 37 roots per explant (see Fig. 1A) with a good regeneration response of $97 \%$ and root length of $6.5 \mathrm{~cm}$ but the reserpine content was nil. The MS media containing 3 $\mathrm{mg} \mathrm{l}^{-1} \mathrm{PABA}+4 \mathrm{mg} \mathrm{l}^{-1}$ NAA showed callus formation with a small number of roots (Table 1). While the combination of IBA and NAA showed good response in terms of regeneration and root formation, however, 
Table 1: Effect of growth regulators with solid MS media on regeneration and reserpine content of roots developed from leaf explant of $R$. serpentina

\begin{tabular}{|c|c|c|c|c|}
\hline $\begin{array}{c}\text { Growth regulator } \\
\left(\mathrm{mg} \mathrm{I}^{-1}\right)\end{array}$ & $\begin{array}{l}\text { Regeneration } \\
\text { response (\%) }\end{array}$ & $\begin{array}{l}\text { No. of roots/ } \\
\text { explants }\end{array}$ & $\begin{array}{l}\text { Root length } \\
\text { (cm) }\end{array}$ & $\begin{array}{l}\text { Reserpine } \\
\text { content (\%) }\end{array}$ \\
\hline $\begin{array}{l}\text { NAA (4.5) } \\
\text { NAA (5.5) } \\
\text { NAA (6) } \\
\text { NAA (6.5) } \\
\text { NAA (8.5) } \\
\text { NAA (9) } \\
\text { NAA (9.5) } \\
\text { NAA (10) } \\
\text { PABA (0.5) + NAA (3) } \\
\text { PABA (1) + NAA (3) } \\
\text { PABA (3) + NAA (3) } \\
\text { PABA (1) + NAA (4) } \\
\text { PABA (2) + NAA (4) } \\
\text { PABA (3) + NAA (4) } \\
\text { IBA (3) + NAA (2) } \\
\text { IBA (2) + NAA (4) } \\
\text { IBA (2) + NAA (4.5) } \\
\text { IBA (2) + NAA (5) } \\
\text { IAA (0.5) + NAA (2) } \\
\text { IAA (5) + NAA (5) } \\
\text { BAP (5) + NAA (2) } \\
\text { BAP (5) + NAA (3) } \\
\text { BAP (5) + NAA (3.5) }\end{array}$ & $\begin{array}{l}52.23 \pm 0.39^{\mathrm{a}} \\
45.51 \pm 0.52^{\mathrm{bc}} \\
77.30 \pm 0.87^{\mathrm{c}} \\
52.76 \pm 0.35^{\mathrm{bc}} \\
48.28 \pm 0.44^{\mathrm{ab}} \\
89.52 \pm 0.37^{\mathrm{c}} \\
82.44 \pm 0.53^{\mathrm{b}} \\
52.80 \pm 0.21^{\mathrm{de}} \\
31.55 \pm 0.81^{\mathrm{c}} \\
71.17 \pm 0.66^{\mathrm{c}} \\
43.72 \pm 0.25^{\mathrm{b}} \\
97.33 \pm 0.45^{\mathrm{c}} \\
58.69 \pm 0.55^{\mathrm{a}} \\
92.40 \pm 0.29^{\mathrm{bc}} \\
63.94 \pm 0.06^{\mathrm{e}} \\
87.31 \pm 0.37^{\mathrm{d}} \\
93.15 \pm 0.19^{\mathrm{ab}} \\
95.67 \pm 0.33^{\mathrm{e}} \\
37.12 \pm 0.59^{\mathrm{c}} \\
25.88 \pm 0.08^{\mathrm{bc}} \\
97.30 \pm 0.51^{\mathrm{ab}} \\
92.53 \pm 0.73^{\mathrm{d}} \\
95.17 \pm 0.44^{\mathrm{b}}\end{array}$ & $\begin{array}{c}7.35 \pm 0.72^{\mathrm{b}} \\
13.53 \pm 0.65^{\mathrm{bc}} \\
12.37 \pm 0.50^{\mathrm{de}} \\
7.51 \pm 0.81^{\mathrm{c}} \\
{ }^{*} 8.93 \pm 0.70^{\mathrm{cd}} \\
14.21 \pm 0.66^{\mathrm{bc}} \\
{ }^{*} 11.37 \pm 0.43^{\mathrm{a}} \\
8.20 \pm 0.75^{\mathrm{bc}} \\
{ }^{*} 5.72 \pm 0.63^{\mathrm{ab}} \\
12.08 \pm 0.32^{\mathrm{e}} \\
{ }^{*} 8.31 \pm 0.85^{\mathrm{c}} \\
37.10 \pm 0.93^{\mathrm{d}} \\
19.37 \pm 0.59^{\mathrm{ab}} \\
{ }^{*} 1.93 \pm 0.38^{\mathrm{de}} \\
{ }^{*} 7.39 \pm 0.41^{\mathrm{bc}} \\
23.85 \pm 0.71^{\mathrm{a}} \\
28.07 \pm 0.33^{\mathrm{c}} \\
30.51 \pm 0.64^{\mathrm{bc}} \\
2.91 \pm 0.70^{\mathrm{d}} \\
2.10 \pm 0.43^{\mathrm{ab}} \\
* 1.81 \pm 0.51^{\mathrm{e}} \\
{ }^{*} 3.17 \pm 0.43^{\mathrm{cd}} \\
* 3.40 \pm 0.82^{\mathrm{c}}\end{array}$ & $\begin{array}{l}5.22 \pm 0.81^{\mathrm{ab}} \\
4.90 \pm 0.31^{\mathrm{d}} \\
5.37 \pm 0.42^{\mathrm{bc}} \\
4.92 \pm 0.34^{\mathrm{c}} \\
5.95 \pm 0.29^{\mathrm{a}} \\
4.31 \pm 0.78^{\mathrm{cd}} \\
6.18 \pm 0.53^{\mathrm{ab}} \\
5.90 \pm 0.28^{\mathrm{de}} \\
5.55 \pm 0.55^{\mathrm{a}} \\
6.23 \pm 0.35^{\mathrm{c}} \\
5.76 \pm 0.75^{\mathrm{bc}} \\
6.51 \pm 0.87^{\mathrm{de}} \\
5.38 \pm 0.64^{\mathrm{b}} \\
4.55 \pm 0.21^{\mathrm{cd}} \\
4.89 \pm 0.51^{\mathrm{a}} \\
6.26 \pm 0.75^{\mathrm{bc}} \\
6.33 \pm 0.92^{\mathrm{d}} \\
5.85 \pm 0.78^{\mathrm{c}} \\
5.33 \pm 0.19^{\mathrm{ab}} \\
4.90 \pm 0.37^{\mathrm{d}} \\
3.24 \pm 0.22^{\mathrm{c}} \\
2.58 \pm 0.57^{\mathrm{bc}} \\
2.73 \pm 0.18^{\mathrm{e}}\end{array}$ & $\begin{array}{c}\text { nil } \\
\text { nil } \\
0.02 \pm 0.21^{\mathrm{d}} \\
0.01 \pm 0.17^{\mathrm{bc}} \\
0.01 \pm 0.03^{\mathrm{de}} \\
0.02 \pm 0.07^{\mathrm{b}} \\
0.02 \pm 0.15^{\mathrm{cc}} \\
\text { nil } \\
\text { nil } \\
\text { nil } \\
0.03 \pm 0.18^{\mathrm{a}} \\
\text { nil } \\
\text { nil } \\
\text { nil } \\
\text { nil } \\
\text { nil } \\
\text { nil } \\
\text { nil } \\
\text { nil } \\
\text { nil } \\
\text { nil } \\
\text { nil } \\
\text { nil }\end{array}$ \\
\hline
\end{tabular}

${ }^{*}$ Callus growth. Note: Each value represents mean $\pm S E$. Values with the same letter footnote in each column were not significantly different $(P \leq 0.05)$. Codes: $N A A=\alpha$-naphthalene acetic acid; $P A B A=$ paraamino benzoic acid; IBA = 3-Indole butyric acid; IAA = indole-3-acetic acid; $B A P=6$-benzyl aminopurine.

failed to produce reserpine. MS medium supplemented with $3 \mathrm{mg} \mathrm{l}^{-1}$ IBA $+2 \mathrm{mg} \mathrm{l}^{-1}$ NAA produced 7 roots per explant along with callus. IBA $\left(2 \mathrm{mg} \mathrm{I}^{-1}\right)$ in combination with 4.5 and $5 \mathrm{mg} \mathrm{I}^{-1}$ of NAA produced 28 and 30 roots, respectively while the combination of $0.5 \mathrm{mg} \mathrm{l}^{-1}$ BAP and $2 \mathrm{mg} \mathrm{I}^{-1}$ NAA produced only callus (see Fig. 1B). MS media supplemented with IAA $\left(0.5 \mathrm{mg} \mathrm{l}^{-1}\right)+$ NAA (2 $\mathrm{mg} \mathrm{l}^{-1}$ ) gave poor response in terms of root regeneration. A similar response was observed for $5 \mathrm{mg} \mathrm{I}^{-1} \mathrm{IAA}+5 \mathrm{mg} \mathrm{I}^{-1}$ NAA. Higher regeneration response in terms of callus formation was observed for MS medium with BAP and NAA combination, but the number of roots was small (Table 1 and Fig. 1C). Higher reserpine content $(0.03 \%)$ was obtained in MS media supplemented with $3 \mathrm{mg} \mathrm{l}^{-1}$ PABA $+3 \mathrm{mg} \mathrm{l}^{-1}$ NAA. Other combinations of growth regulators - IBA and NAA; IAA and NAA; BAP and NAA - failed to produce reserpine. The explant manifested thin roots in MS media containing $1 \mathrm{mg} \mathrm{I}^{-1}$ PABA $+4 \mathrm{mg} \mathrm{I}^{-1}$ NAA on incubation under dark conditions (see Fig. 1D).

Response of liquid MS media on root induction Liquid MS medium showed a comparatively poor response to root induction when the same combinations of growth regulators as in solid MS media were used. Root induction was observed on liquid MS media supplemented with $4.5 \mathrm{mg} \mathrm{I}^{-1}$ NAA after six weeks of inoculation but other single growth regulators failed to produce roots from the leaf explant. The highest regeneration (51 $\%$ ) was achieved by the combination of $1 \mathrm{mg}$ $\mathrm{I}^{-1}$ PABA $+3 \mathrm{mg} \mathrm{l}^{-1}$ NAA with 5 roots per 
explant and a root length of $4.2 \mathrm{~cm}$. The maximum number of roots regenerated on liquid MS media which was for the combination of $1 \mathrm{mg} \mathrm{l}^{-1} \mathrm{PABA}+4 \mathrm{mg} \mathrm{l}^{-1} \mathrm{NAA}$ was 10 , giving a regeneration response rate of $35 \%$ and root length of $3.8 \mathrm{~cm}$ (see Fig $1 \mathrm{E})$.
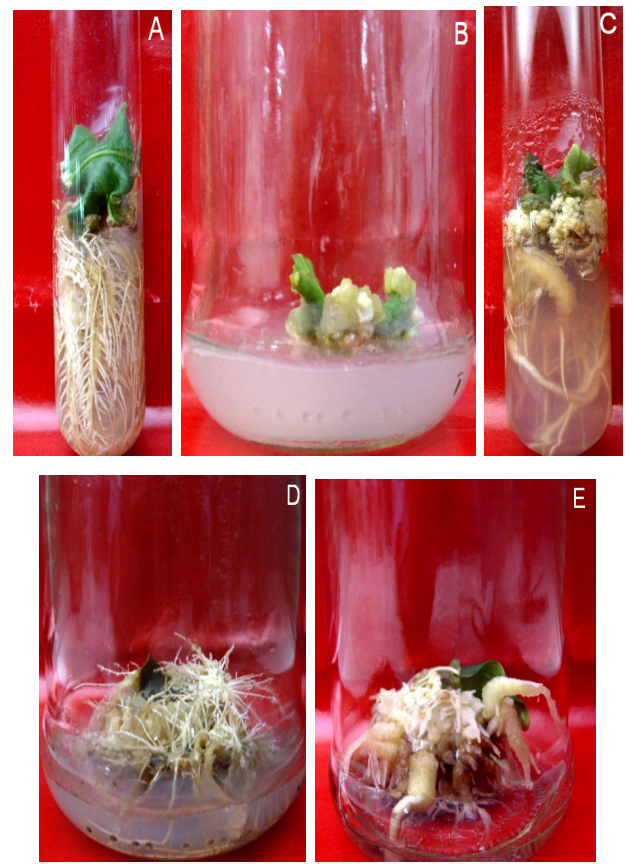

Figure 1: Response of leaf explants of $R$. serpentina: $\mathrm{A}=$ root induction on MS media containing $1 \mathrm{mg} \mathrm{l}^{-1} \mathrm{PABA}+4 \mathrm{mg} \mathrm{l}^{-1} \mathrm{NAA} ; \mathrm{B}=$ callus initiation on MS media containing $0.5 \mathrm{mg} \mathrm{I}^{-1}$ $\mathrm{BAP}+2 \mathrm{mg} \mathrm{l}^{-1} \mathrm{NAA} ; \mathrm{C}=$ callus and root induction on MS media containing $5 \mathrm{mg} \mathrm{l}^{-1} \mathrm{BAP}+3 \mathrm{mg} \mathrm{I}^{-1}$ NAA; $D=$ root induction on MS media containing 1 $\mathrm{mg} \mathrm{l}^{-1}$ PABA $+4 \mathrm{mg} \mathrm{l}^{-1}$ NAA under dark conditions; $\mathrm{E}=$ root induction on liquid MS media containing 1 $\mathrm{mg} \mathrm{l}^{-1} \mathrm{PABA}+4 \mathrm{mg} \mathrm{l}^{-1} \mathrm{NAA}$.

IBA and NAA combinations also produced low regeneration response, yielding a lower number of roots with reduced root length (Table 2). The combination of $0.5 \mathrm{mg} \mathrm{I}^{-1} \mathrm{IAA}$ and $2 \mathrm{mg} \mathrm{I}^{-1}$ NAA elicited a lower regeneration response, i.e. $10 \%$, with the growth of 1 root per explant. All combinations of growth regulators on liquid MS media failed to yield callus and reserpine.

\section{DISCUSSION}

Rauwolfia serpentina is reported to contain a large number of therapeutically useful indole alkaloids and these alkaloids are largely located in the roots. Hence, root biomass production of this plant could be of economic importance. Several investigations have been carried out on in vitro regeneration of roots using leaf as the starting material [22-25].

In the present investigation, various combinations of auxins were employed to promote root growth from Rauwolfia leaf explant. MS media supplemented with PABA $\left(1 \mathrm{mg} \mathrm{l}^{-1}\right)+$ NAA $\left(4 \mathrm{mg} \mathrm{I}^{-1}\right)$ was the best combination for inducing roots of $R$. serpentina by leaf explant technique. On the other hand, the same combination (PABA + $N A A)$ and IBA + NAA in liquid MS media showed poor regeneration with smaller numbers of roots. NAA ( $\left.9 \mathrm{mg} \mathrm{l}^{-1}\right)$, used as a single growth regulator, produced better root induction and reserpine but when combined with a cytokinin (BAP) and auxin (NAA) rooting response with callus formation was poor. Combination of two auxins, such as either PABA and NAA or IBA and NAA, promoted root growth. It is noteworthy that two auxin combinations have been reported to enhance the rooting ability of Chicory leaf explant [26] and alkaloid biosynthesis in a cell suspension culture of Cephaelis ipecacuanha [27]. Various plant types exert different effects on adventitious root induction and elongation as a result of auxin treatment. In general, high levels of auxins promote the production of adventitious roots. Although, auxins inhibited elongation of root, it should be noted that production of lateral roots is an important factor for rapid growth and is responsible for higher biomass in any system. Reduced root growth might have been due to the accumulation of endogenous auxins during each subculture.

Organogenesis in vitro is complex and yet to be understood. Since exogenous auxin increases root production, the roots produced in the absence of exogenous growth regula- 
Table 2: Effect of growth regulators in liquid MS media on root regeneration from leaf explant of $R$. serpentine (mean \pm SEM)

\begin{tabular}{lccc}
\hline $\begin{array}{c}\text { Growth regulators } \\
\left(\mathrm{mg} \mathrm{l}^{-1}\right)\end{array}$ & $\begin{array}{c}\text { Regeneration } \\
\text { response }(\%)\end{array}$ & $\begin{array}{c}\text { No. of roots/ } \\
\text { explant }\end{array}$ & $\begin{array}{c}\text { Root length } \\
(\mathrm{cm})\end{array}$ \\
\hline NAA (4.5) & $33.56 \pm 0.22^{\mathrm{a}}$ & $3.02 \pm 0.81^{\mathrm{bc}}$ & $4.15 \pm 0.37^{\mathrm{d}}$ \\
NAA (6) & $40.91 \pm 0.38^{\mathrm{d}}$ & $5.17 \pm 0.44^{\mathrm{a}}$ & $3.93 \pm 0.73^{\mathrm{ab}}$ \\
NAA (9) & $34.31 \pm 0.57^{\mathrm{bc}}$ & $6.01 \pm 0.61^{\mathrm{bc}}$ & $4.10 \pm 0.23^{\mathrm{c}}$ \\
NAA (9.5) & $28.75 \pm 0.29^{\mathrm{c}}$ & $2.21 \pm 0.35^{\mathrm{cd}}$ & $3.57 \pm 0.70^{\mathrm{b}}$ \\
NAA (10) & $25.29 \pm 0.33^{\mathrm{e}}$ & $2.93 \pm 0.57^{\mathrm{c}}$ & $2.81 \pm 0.19^{\mathrm{c}}$ \\
PABA (1) + NAA (3) & $51.13 \pm 0.84^{\mathrm{d}}$ & $5.08 \pm 0.37^{\mathrm{b}}$ & $4.28 \pm 0.59^{\mathrm{bc}}$ \\
PABA (1) + NAA (4) & $35.60 \pm 0.87^{\mathrm{bc}}$ & $10.16 \pm 0.17^{\mathrm{cd}}$ & $3.86 \pm 0.35^{\mathrm{e}}$ \\
PABA (2) + NAA (4) & $28.22 \pm 0.92^{\mathrm{a}}$ & $6.73 \pm 0.41^{\mathrm{ab}}$ & $4.55 \pm 0.15^{\mathrm{ab}}$ \\
IBA (3) + NAA (2) & $21.28 \pm 0.58^{\mathrm{c}}$ & $2.83 \pm 0.39^{\mathrm{cd}}$ & $3.73 \pm 0.80^{\mathrm{a}}$ \\
IBA (2) + NAA (4.5) & $33.71 \pm 0.21^{\mathrm{bc}}$ & $5.71 \pm 0.63^{\mathrm{b}}$ & $4.04 \pm 0.39^{\mathrm{d}}$ \\
IBA (2) + NAA (5) & $29.94 \pm 0.52^{\mathrm{a}}$ & $3.90 \pm 0.31^{\mathrm{ab}}$ & $3.21 \pm 0.18^{\mathrm{de}}$ \\
IAA (0.5) + NAA (2) & $10.52 \pm 0.35^{\mathrm{d}}$ & $0.93 \pm 0.20^{\mathrm{e}}$ & $3.49 \pm 0.33^{\mathrm{b}}$ \\
\hline
\end{tabular}

Values with the same letter footnote in each column were not significantly different $(P \leq 0.05)$.

Codes: $N A A=\alpha$-naphthalene acetic acid; $P A B A=$ para-amino benzoic acid; IBA = 3-Indole butyric acid; $I A A=$ indole-3-acetic acid; $B A P=6$-benzyl aminopurine

tors probably reflect the endogenous auxin level. We observed that the quantity of NAA present in the culture media showed pronounced effect on the regenerated roots and on their biosynthetic potential for alkaloid profile. These results suggest that the quality and quantity of auxins supplemented to the culture of leaf explant affected the type of regeneration as well as secondary metabolite production, as has been reported in several other organ culture $[28,29]$.

The low reserpine content of the in vitro regenerated roots found in the present work may be attributed to two factors. First, roots regenerated from leaf explant which are known for low alkaloid content. Second, the regenerated roots lacked a bark and the bark of the plant is reported to contain higher alkaloid content than the root [30]. The production of tropane alkaloids in the hairy root culture of Hyoscyamus muticus declined dramatically when the roots were induced to form callus and reappeared with redifferentiation of roots [31]. Also, accumulation of most secondary metabolites appears to be developmentally regulated [32]. In our study, increase in reserpine content gave rise to fewer number of roots. Thus, secondary metabolite production and root induction appear to be somewhat correlated. We also observed that $R$. serpentina explant incubated under dark conditions produced thin roots which indicated that photoperiod also influences in vitro root growth.

Overall, therefore, the results show that solid MS media is good for root induction from the leaf explant of $R$. serpentina. On the other hand, liquid MS media inhibited percentage of regeneration, root growth, root length, and reserpine content. This effect may due to the production of some metabolites that accumulated in the liquid culture and exerted inhibitory effect during the course of root growth. However, this hypothesis will need to be verified in future studies.

\section{CONCLUSION}

Development of a simple protocol for in vitro growth of roots from the leaf explant of $R$. serpentina using different concentrations and combinations of plant growth regulators and culture conditions was achieved. The technique is superior to methods such as shoot organogenesis, callus morphogenesis and Agrobacterium rhizogenes-mediated 
transformation. The technique seems better than the hairy root culture method using Agrobacterium, and should further investigated for enhanced alkaloid production by $R$. serpentina roots.

\section{ACKNOWLEDGEMENT}

The authors wish to acknowledge the contribution of Drs KK Janardhan and A Patani for helpful discussions and guidance during this research.

\section{REFERENCES}

1. Klushnichenko VE, Yakimov SY, Tuzova TP, Syagailo YV, Kuzovkina IN, Vulf'son AN, Miroshnikov Al. Determination of indole alkaloids from $R$. serpentina and $R$. vomitoria by HPLC and TLC methods. $J$ Chromat 1995; 704: 357-362.

2. Von Poser G, Andrade $H H$, Da Silva KV, Henriques AT, Henriques JA. Genotoxic, mutagenic and recombinogenic effects of Rauwolfia alkaloids. Mutat Res 1990; 232: 37-43.

3. Stanford JL, Martin EJ, Brinton LA, Hoover RN. Rauwolfia use and breast cancer: $A$ casecontrol study. J Natl Cancer Inst 1986; 76: 817-822.

4. Pullaiah J. Medicinal plants in India, Vol. II. New Delhi: Regency Publ; 2002; pp 441-443.

5. Kokate $C K$, Purohit $A P$, Gokhale $S B$. Pharmacognosy. Pune: Nirali Prakashan; 1998; pp 369-373.

6. Farooqi $A A$, Sreeramu BS. Cultivation of medicinal and aromatic crops. Hyderabad: Universities Press; 2001; pp 210-211.

7. Coleman WK, Greyson RI. Root regeneration from leaf cuttings of Lycopersicon esculentum Mill: Application of the leaf plastochron index and responses to exogenous Gibberellic acid. J Exp Bot 1976; 27: 1339-1351.

8. Attfield EM, Evans PK. Developmental pattern of root and shoot organogenesis in cultured leaf explants of Nicotiana tabacum. J Exp Bot 1991; 42: 51-57.

9. Tran Thanh Van M, Chlyah H, Chlyah A. Tissue culture and plant science. London: Academic Press; 1974. pp. 174.

10. Shrivastava N, Padhya MA. Punarnavine profile in the regenerated roots of Boerhaavia diffusa from leaf segments. Curr Sci 1995; 68: 653-656.

11. Martin KP, Zhang CL, Hembrom ME, Slater A, Madassery J. Adventitious root induction in Ophiorrhiza prostrata: a tool for the production of camptothecin (an anticancer drug) and rapid propagation. Plant Biotech Rep 2008; 2: 163-169.

12. Tuan NS, Ngoc HM, Mai NT, Quyen NT, Hai NT, Nhut DT. Shoot and root direct regeneration from cultured leaf segment of Lisianthus (Eustoma grandiflorum) in vitro. TC Cong nghe sinh hoc 2006; 4: 249-256.

13. D'onofrio C, Morini S. Somatic embryo, adventitious root and shoot regeneration in in vitro grown Quince leaves as influenced by treatment of length with growth regulators. Scie Horti 2006; 107: 194-199.

14. Samaj J, Bobak M, Kubosnikova D, Kristin J, Kolarik E, Ovecka M, Blehova A. Bundle sheet cells are responsible for direct root regeneration from leaf explants of Helianthus occidentalis. J Plant Physiol 1999; 154: 89-94.

15. Roja G, Heble MR. Indole alkaloids in clonal propagules of Rauwolfia serpentina. Plant Cell Tissue Org Cult 1996; 44(2): 111115.

16. Pandey VP, Kudakasseril J, Cherian E, Patani G. Comparison of two methods for in vitro propagation of Rauwolfia serpentina from nodal explants. Indian Drugs 2007; 44: 514-519.

17. Benjamin $B D$, Roja G, Heble MR. Agrobacterium rhizogenes mediated tranformation of Rauvolfia serpentina: Regeneration and alkaloid synthesis. Plant Cell Tiss Org Cult 1993; 35: 253-257.

18. Falkenhagen $H$, Kuzovkina IN, Alterman IE, Nikolaeva LA, Stockigt J. Alkaloid formation in hairy roots and cell suspensions of Rauwolfia serpentina Benth. Nat Prod Res 1993; 3: 107-112.

19. Banerjee S, Kukreja AK, Kahol AP, Kumar S. Bioreactor for enhancing the biomass of plant organs. 2003; US Pat 6589780B2.

20. Murashige T, Skoog FA. Revised medium for rapid growth and bioassay with tobacco tissue culture. Physiol Plant 1962; 15: 473-497.

21. Indian Pharmacopoeia. Ghaziabad: The Indian Pharmacopoeia Commission; 2007. pp 2062-2063.

22. Perveen R, Ilahi I. Callus formation in Rauwolfia serpentina. Pakistan J Bot 1978; 10: 141148.

23. Sehrawat AR, Uppal S, Punia A. In vitro culture and multiplication of Rauwolfia serpentina - A threatened medicinal plant. Crop Res 2001; 22: 68-71.

24. Bhatt $R$, Arif $M$, Gaur AK, Rao PB. Rauwolfia serpentina: Protocol optimization for in vitro propagation. Afr $J$ Biotech 2008; 7: 4265-4268.

25. Klushnichenko VE, Yakimov SY, Bychkova TP, Kuzovkina IN, Vulf'son AN, Miroshnikov 
Al. Separation of indole alkaloids from $R$. serpentina and $R$. vomitoria by HPLC and TLC methods. Pharma Chem J 1994; 28: 58-61.

26. Nandagopal $S$, Ranjitha Kumari BD. Effectiveness of auxin induced in vitro root culture in Chicory. J Cent Eur Agric 2007;8:73-80.

27. Jha S, Sahu NP, Sen J, Jha TB, Mahato SB. Production of emetine and cephaeline from cell suspension and excised root cultures of Cephaelis ipecacuanha. Phytochemistry 1991; 30: 3999-4003.

28. Mantell SH, Smith $\mathrm{H}$. Plant Biotechnology. Cambridge: Cambridge University Press; 1983; pp 75-107.
29. Ruyter CM, Mahmood A, Illahi I, Stockigt J. Investigation of the alkaloid content of Rauwolfia serpentina roots from regenerated plants. Planta Med 1991; 57: 328-330.

30. Anonymous. The Wealth of India - Raw materials, Vol. III. New Delhi: CSIR, 1995; pp 383-384.

31. Flores HE, Hoy MW, Pickard J. Secondary metabolites from root cultures $-A$ review. Trends Biotech 1987; 5: 64-69.

32. Bhojwani SS, Razdan MK. Production of secondary metabolites. In: Plant Tissue Culture: Theory and Practice (Rev. ed), Amsterdam: Elsevier, 2005; pp 537-562. 